\title{
MILITÊRE GEWOONTES EN TRADISIES/MILITARY CUSTOMS AND TRADITIONS
}

\begin{abstract}
Vaandels
Regimentsvaandels het ontwikkel uit die baniere van die Middeleeuse adellikes wat op hul beurt weer hul ontstaan gehad het uit die vlae en standaarde van die Romeine, Grieke en Egiptenare. In hul vroegste vorm is vaandels en standaarde gebruik vir die uitsluitlike doel om vriend en vyand in die hitte van die stryd uit mekaar te ken.

Die waardigheid waarmee vaandels vandag bejeën word is nie oornag verwerf nie maar het ontstaan as gevolg van 'n gestadigde evolusie. Selfs nog voor die Romeine. Grieke en Egiptenare met hul gebruik van vaandels en standaarde begin het, het die primitiewe mens uitkentekens op sy lyf geverf om stamverwantskap aan te dui.
\end{abstract}

Die ou Romeine het ' $n$ Vixillum (wimpel) gehad waarop ' $n$ arend afgebeeld was en deur alle Romeine met piëteit bejeën was. Vordering is met lyfpantsering gemaak en weereens om vriend en vyand te onderskei is persoonlike baniere op die pantser of skild van die leier geverf.

Met die verskyning van die huursoldaat het die vaandels die kleure en simbole van die landsheer bevat wat die huursoldate wat in sy diens geveg het, besoldig het. In ander gevalle was die vaandel versier met die kleure van die offisier wat so ' $n$ afdeling gevorm en van klerasie en wapens voorsien het voordat hy die bepaalde afdeling of eenheid verhuur het om vir ' $n$ vors (betaalheer) tot die stryd toe te tree. So is die ou familiewapen van die adellikes op die banier vervang deur dié van die professionele leiers wat die edelmanne as aanvoerders verdring het.

Die vaandel het egter terselfdertyd ook as 'n saamskaarpunt voor of tydens ' $n$ geveg gedien en het ook 'n simbool van regimentslewe en esprit de corps geword. Aangesien die uniform, soos dit vandag bekend is, eers later ontstaan het, het die vaandel dus 'n belangrike funksie vervul.

As gevolg hiervan is die vaandel nie alleen as buitengewoon belangrik beskou nie, maar tewens onlosmaaklik verbind met die krygsmans- eer van ' $n$ bepaalde eenheid. Om ' $n$ vaandel tydens 'n slag te verloor, was 'n onherstelbare verlies. Die dra van die vaandel is, in die verlede, aan ' $n$ verteenwoordiger van die adel of ' $n$ vername persoon van burgerlike herkoms opgedra. Hy het bekend gestaan as die vaandrig en is verplig geag om sy lewe op te offer vir die kosbare pand wat aan hom toevertrou was. Om hierdie rede was die sterftesyfer onder die vaandeldraers gevolglik baie hoog en in 1882 is daar dus besluit om nie meer vaandels op die slagveld te neem nie. Vandag word die gebruik van die vaandel tot belangrike militêre parades beperk.

Dit is interessant om daarop te let dat die laaste geleentheid waar 'n vaandel van 'n Britse regiment op die slagveld saamgeneem is tydens die slag van Laingsnek (28 Januarie 1881) was.

Die eerste verwysing na ' $n$ vaandel in ' $n$ suiwer Suid-Afrikaanse konteks word gevind in die Resoulusies van die Politieke Raad van Dinsdag 11 November 1664. Hierdie Raad was die hoogste regeringsliggaam aan die Kaap die Goeie Hoop (1652-1795). Hiervolgens is die burgers en boere wat weg van die Fort gewoon het, in 'n gewapende kompanie gevorm en 'n blou vaandel is aan hulle toegeken.

Agt jaar later en wel op 3 September 1672 het dieselfde Raad beslis dat alle dienaars van die Hollandse Oos Indiese Kompanie in vyf afdelings verdeel moes word en dat aan elke afdeling 'n vaandel met 'n spesifieke kleur toegeken word. Ook die Burgermilisie is in twee kompanies verdeel, elk met sy eie vaandel.

Voorskrifte het ook bepaal dat wanneer sekere waarskuwingsseine gegee word moes burgers by hul vaandels vergader.

Die Britse okkupasie van die Kaap het ' $n$ volgende fase in die ontwikkelingsgeskiedenis van die Suid-Afrikaanse vaandel gebring deurdat daar kennis gemaak is met die toekenning van konings/koninginsvaandels en/of regimentsvaandels aan Infanterie-eenhede. 
Oor die jare is 'n aantal van hierdie konings/koninginsvaandels aan verskeie van die Koloniale-, Milisie- en latere Suid-Afrikaanse eenhede toegeken. Met die totstandkoming van die Republiek van Suid-Afrika op 31 Mei 1961 het hierdie Britse gebruik onvanpas geraak en is alle sodanige vaandels met die nodige seremonie weggelê.

Gedurende die genoemde Britse tydperk tot en met Uniewording op 31 Mei 1910 is daar ook 'n groot aantal regimentsvaandels aan Kaapse en Natalse Vrywilligereenhede toegeken. Die Kommandos van die Republiek va die Oranje-Vrystaat en die Zuid-Afrikaansche Republiek het nie die gebruik oorgeneem nie en dus geen vaandel gedra nie.

Sedert Uniewording is regimenstvaandels in ' $n$ toenemende aantal toegeken, selfs aan twee Staande Mageenhede naamlik die Spesiale Diensbataljon en die Suid-Afrikaanse Militêre Kollege. Dit is interessant om daarop te let dat met die ingebruikneming van die vaandel van die Suid-Afrikaanse Militêre Kollege dit ook gebruik geword het om die springbok as die nasionale embleem bo-op die vaandelstok aan te bring.

Pogings is ook aangewend om vaandels vir Kommandos daar te stel. Hoewel daar ' $n$ vyftigtal bestel is, is hierdie vaandels vanweë die oorlog en sekere organisatoriese veranderings aan die kommandostelsel nooit amptelik in gebruik geneem nie.

Republiekwording op 31 Mei 1961 het 'n totale nuwe beleid tot gevolg gehad. Die geleentheid is geskep om alle aspekte van vaandels op 'n geordende grondslag te plaas. Soos voorheen is gehou by die gebruik dat slegs Infanterie, Pantser en Pantserkareenhede regimentsvaandels mag dra. Hierdie gebruik is in 1970 uitgebrei sodat alle dienswapen- en diensvakeenhede insluitende kommando-eenhede aanspraak kan maak op 'n vaandel.

Met die toekenning van vaandels aan 2 en 24 Eskaders van die Suid-Afrikaanse Lugmag op 3 Mei 1966 is die vaandeltradisie ook na die SuidAfrikaanse Lugmag oorgedra. ' $n$ Eskader is tans die enigste formasie in de Suid-Afrikaanse Lugmag wat geregtig is om ' $n$ vaandel te dra.

Hoewel die Suid-Afrikaanse Vloot of enige van sy eenhede nooit ' $n$ vaandel gedra het nie is daar in 1952 magtiging ontvang om die Vlootvlag by spesiale geleenthede te dra. Op 12 April 1969 is 'n amptelike vaandel aan die Suid-Afrikaanse Vloot oorhandig vir gebruik by sekere spesiale geleenhede.

Uit bostaande is dit duidelik dat die Suid-Afrikaanse Weermag ook sy stempel afgedruk het op die ontwikkeling van die vaandel en die tradisie daaraan gekoppel. Die vaandel bly die een visuele simbool waardeur die eer, tradisie en dade van 'n eenheid na vore gebring word en waarop oud, huidige en toekomstige lede van so 'n eenheid opreg trots kan wees.

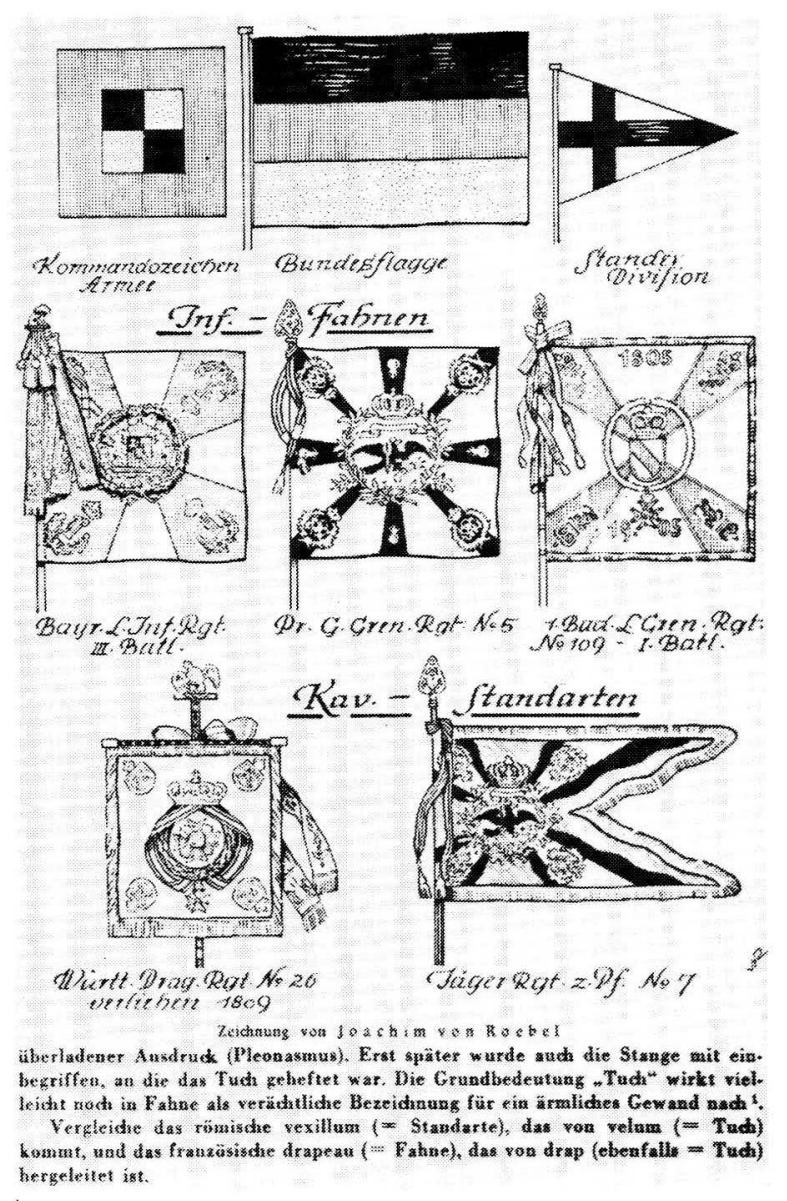

Voorbeelde van vroeëre Duitse Infanterie Vaandels en Kavalerie Standaarde

\section{Military Funerals}

The symbolism associated with military funerals has several features of historical interest.

One of the most interesting is the practice of reversing arms during a military funeral, a custom which has evolved in British military tradition although it is no longer adhered to by the SADF, with the exception of the Navy. The explanation behind the custom is that death puts the rifle to 
shame, and the reversal of the barrel is a fitting sign of reverence.

The significance of draping the National Flag over the coffin during a military funeral is simply to denote that the deceased has died in the service of the State, and that the State accepts the responsibility for what it ordered him to do.

There is some dispute concerning the origin and significance of firing three volleys at the graveside. In ancient times it appears that soldiers at the graveside were detailed to draw their swords and to strike three times into the air to drive the demons from the spirit or heart of the deceased soldier - the door of men's hearts was supposed to stand ajar at such times. When firearms replaced the sword, three volleys were fired, symbolizing in some armies the stages in the life of a soldier - his birth, manhood and death. In Britain it seems as if the three volleys are fired in the name of the Holy Trinity. In the SADF the custom of firing three rifle volleys for all officers under the rank of Brigadier-General and for soldiers has lapsed, although gun salutes are fired for officers of general rank.

The 'Last Post' sounded at military funerals is the 'Nunc Dimittis' of the dead soldier, airman or sailor. The high note on which it ends is designed to express hope and expectation, and this is emphasized, after a pause, by the 'Reveille' which anticipates the resurrection.

The origin of pall-bearers seems to derive from the old practice of carrying the mantle or pall of the deceased alongside the body so as to drape it over the body on the way to the grave - by this action preventing demons and devils from entering the body whilst on the journey to the grave. Thus evolved the custom of having pall-bearers (to carry the deceased's mantle) in addition to the actual bearer of the coffin. 